Goin, entitled "Mach Tables for Real Gas Equilibrium Flow of Air in Hypervelocity Test Facilities with Total Temperatures to $10,000^{\circ} \mathrm{K} . "$. This report tabulates the aerodynamic flow parameters for isentropic expansions and flow through normal shocks in the pressure range 100-4,000 atmospheres. Both the bibliography and the monograph are available, price 0.75 and 2.0 dollars, respectively, from the Office of Technical Services, Department of Commerce, Washington 25, D.C.

\section{Gairdner Foundation Awards}

Gatrdner Foundation awards have been made to the following in recognition of their contributions to the study of arthritis and heart diseases: Dr. Alan C. Burton, professor of biophysics, University of Western Ontario, for his work on blood circulation; Sir Russell Brock, cardiac surgeon at Guy's Hospital and Brompton Hospital, London, for his work on heart surgery; Dr. Jonas H. Kellgren, professor of rheumatology and director of the Rheumatism Research Centre, University of Manchester, for his work on the incidence of rheumatoid arthritis; Dr. Alexander B. Gutman, director of the Department of Medicine, Mount Sinai Hospital, Now York City, for his work on the treatment of gout; Dr. U. S. von Euler, professor of physiology, Karolinska Institutet, Stockholm, for his work on noradrenaline and its effects on body functions.

The Royal Institution of Naval Architects: Awards

THE Council of the Royal Institution of Naval Architects has announced the following awards: Denny Scholarship in Marine Engineering (1961), to Mr. David K. Brown (17), of Kelvinside Academy, Glasgow ( $£ 350$ per annum for four years at the University of Glasgow); Parsons Scholarship in Marine Engineering (1961), to Mr. Alan B. Turner (21), of Messrs. Alfred Holt and Co., Ltd., Liverpool ( $£ 400$ per annum for three years at the University of Durham, King's College, Newcastle upon Tyne).

\section{The Meldola Medal for 1961}

The Meldola Medal is the gift of the Society of Maccabrans and is normally awarded annually. The next award will be made early in 1962 to the chemist who, being a British subject and under thirty years of age at December 31, 1961, shows the most promise as indicated by his or her published chemical work brought to the notice of the Council of the Royal Institute of Chemistry before December 31, 1961 . No restrictions are placed upon the kind of chemical work or the place in which it is conducted. The merits of the work may be brought to the notice of the Council, either by persons who desire to recommend the candidate or by the candidate himself, by lotter addressed to the President, Royal Institute of Chemistry, 30 Russell Square, London, W.C.I.

\section{The Association of Clinical Biochemists}

THE following officers were olected at the annual general meeting of the Association of Clinical Biochemists: President, Dr. A. L. Latner; Chairman, Mr. H. Varley; Honorary Treasurer, Dr. R. Gaddie; Honorary Secretary, Dr. J. H. Wilkinson, Westminster Medical School, Horseferry Road, London, S.W.1.

\section{Announcements}

Dr. RatPh P. Hudson has been appointed chief of the Heat Division at the National Bureau of
Standards, U.S. Department of Commerce. He succeeds Dr. Charles M. Herzfeld, who was recently appointed essociate director of the Bureau.

THere will be open days at the Humber Laboratory at Hull of the Department of Scientific and Industrial Research on November 9 and 10. Exhibits will include some of the work of the parent laboratory, the Torry Research Station at Aberdeen. Both laboratories deal with the handling, processing and distribution of fish.

Tre Welsh Soils Discussion Group will meet at the Department of Biochemistry and Soil Science, School of Agriculture, Bangor, on November 15. The subject for discussion is "Aspects of the Dynamic Organic Matter Cycle in Soils". Further information is available from Mr. J. A. Taylor, University College, Alexandra Road, Aberystwyth.

The four hundred and tenth meeting of the Biochemical Society, for the presentation of original communications, will be held in the Department of Biochemistry, Manchester College of Science and Technology, on November 11. Further information can be obtained from Dr. W. J. Whelan, Lister Institute of Preventive Medicine, Chelsea Bridge Road, London, S.W.1.

THE office of the Biochemical Society and the editorial office of The Biochemical Journal have now moved to 20 Park Crescent, Regent's Park, London, W.1. All communications connected with The Biochemical Journal should be sent to that address.

A SPECIALISTs' conference on culture collections will be held in Ottawa, Canada, during August 27-28, 1962. Topics for discussion will include fundamental and technical aspects of the preservation of culture of micro-organisms and other cells. Special emphasis will be placed on the maintenance of morphological, physiological and genetical characteristics. Attendance at the conference will be by invitation only. Persons interested in attending are invited to write to Dr. S. M. Martin, Division of Applied Biology, National Research Council, Ottawa, Canada, before December 1, 1961.

THe first Feldberg Foundation Lecture 1961 will be given by Prof. Herbert Hensel, director of the Physiological Institute of the University of Marburg, who will speak on "The Electro-physiology of Thermoreceptors" on November 2 in the Physiology Theatre, University College, London, Gower Street, W.C.1. The Foundation was recently instituted (see Nature, 191, 1143; 1961) to encourage GermanEnglish scientific exchange for experimental medical research. Further information can be obtained from Dr. M. Godfrey, Medical Research Council, 20 Park Crescent, Regent's Park, London, W.I.

THe Czechoslovak Society of Arts and Sciences in America will hold its first national scientific congress in the Hotel Statler, Washington, D.C., during April 20-22, 1962. There will be a two-day symposium on the contributions of the Czechoslovak science and arts to world culture. The programme will include papers on science, medicine and technology; fine arts; literature and literary criticism; slavistics and linguistics; law and economies; history and political science; philosophy and sociology; and finally a special section will be devoted to Czechs and Slovaks abroad. Further information can be obtained from Dr. M. Rechcigl, jun., secretary, Programme Committee, 1703 Mark Lane, Rockville, Md. 